\title{
Model Comparison of The Floating Foundations for The Development of Floating Houses at Coastal Areas
}

\author{
Son Haji ${ }^{1}$, Henny Pratiwi Adi ${ }^{2}$, Moch Faiqun Ni'am² \\ Master of Civil Engineering, Sultan Agung Islamic University ${ }^{1,2,3}$ \\ *Corresponding author: Son_hadjie@yahoo.co.id
}

\begin{abstract}
Floating house is a building, which stands or floats on water by relying itself on the weight and the area sunk as the load parameter compatible to the structure. This house can float or be placed on the seashore on the water. This research was conducted by comparing the magnitude of the floating force ( $F a)$ of the three foundation materials of the houses, namely plastic drum, Styrofoam and bamboo. The materials were calculated based on the total load of the house $(G)$, with the safety number of 1.5. .

The research result is the total load of the floating house structure $(G)$ is 364.585,5 Newton (down), the floating force ( $\mathrm{Fa}$ ) magnitude of plastic drum as the foundation material is 549,814 Newton (upward), Styrofoam as the foundation material is 552,720 Newton (upward), and Bamboo as the foundation material is 540,883 Newton (upward). The amounts of the foundation materials for plastic drum are 232 pieces, for Styrofoam are 56 sheets, and for bamboo are 3900 sticks.
\end{abstract}

Keywords: Floating house, floating foundation, floating force, plastic drum, Styrofoam, bamboo

\section{Introduction}

At present, the development of residence in the coastal areas becomes the most important part in sustaining a continuous development, which leads to national welfare improvement, particularly to the people living in the area. Coastal area has a promising potential and becomes substantial factors, which improve the national economy. In both developed and developing countries, economic activities in the area are dominant following the population growth. This situation has direct impacts on the housings and settlements. But unfortunately, these housings and settlements in the area are not well organized and appear to be seedy, densely populated and uninhabitable.

In the frame of the research, the researcher would do analysis and comparison towards the floating house structure using plastic drum, Styrofoam, bamboo as the bottom structure or floating foundation. Other than analyzing the use of different foundation materials, the researcher would design a simple and economic floating house, which could be applied as a residential house for people living in the coastal areas. For the sloof, column and back ring structure, wooden materials were used. For truss, lightweight steel was applied, while for the top cover, Sakura roof was used. 


\section{Definition of Floating House}

Based on the Law No. 4, year 1982 on housing, house is "a building that functions as a domicile and means of building a family". It is a place of commodity if interpreted as a noun and will be a state or process of human in building its occupant if interpreted as a verb, (Turner 1972 in Masri, 2010).

Floating house is a building structure built to float on water using a foundation system that has a high floating force, so it is able to hold the structure of the building above it which experiences from up and down movements according to the height (level) of the water (Asrasal, 2018).

\subsection{Plastic Drum as Foundation Material}

Foundation of the floating house design is a structure under the house that serves to withstand the total load of the house in order to float. The foundation materials of the house are the materials made of plastic drum, which has good, floating force, is light and is easy to find, as it is available around us.

\subsection{Styrofoam as Foundation Material}

Styrofoam is a material derived from a substance b polystyrene (PS). In the process of its production, it is mixed with air bubbles, so it can expand. It is light, as light as foam. In the construction of the foundation, the Styrofoam used was a beam Styrofoam with the length of two meters, width of one meter, and thickness of half meter. For the amount, it is tailored to the need. The bigger and heavier the design of building is, the more Styrofoam is needed.

\subsection{Bamboo as Foundation Material}

Bamboo is a light, hollow material. Most people think that the cavity in the middle of the bamboo is a weakness, and that is not true. The bamboo inside is hollow, but the central cavity on the bamboo is actually a strength and serves as a bracer. Bracers can reinforce bamboo and make the elements commonly used as structures lighter and less rigid. Bamboo is also elastic and does not break easily, so making bamboo structures stronger and more reliable. Because of its natures, which are light, hollow and strong, this 
material is often used in the construction of floating houses or rafts in Indonesia. Bamboo serves as a foundation for lifting the building's loads so that it can float.

\subsection{Determining Material Weigh (G)}

Material weight $(\mathrm{G})$ is the multiplication between the weights from the floating house component, which is multiplied with the weight of the floating house material.

$\mathrm{G}=\mathrm{V} \times \rho$

Where :

G : Specific grafity $(\mathrm{kg})$

$\mathrm{V}$ : Material Volume $\left(\mathrm{m}^{3}\right)$

$\rho \quad$ : Specific grafity $\left(\mathrm{kg} / \mathrm{m}^{3}\right)$

\subsection{Determining the Magnitude of the upward force $(\mathrm{Fa})$ at the Floating Foundation}

$\mathrm{Fa}=\frac{\mathrm{d}^{2}}{\text { 4.p.g.1 }}$

Where :

$\mathrm{Fa} \quad$ : Floating force of completely submerged material (Newton)

$\rho \quad:$ Fluid Density $\left(\mathrm{kg} / \mathrm{m}^{3}\right)$

d : Diameter of floating foundation

$\pi \quad: 3.14$

g : Acceleration of gravity $\left(\mathrm{m} / \mathrm{s}^{2}\right)$

1 : Length of foundation material (m)

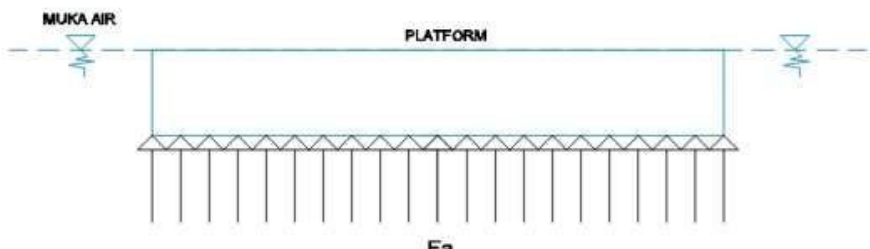

Figure 1. Upward pressure on the floating foundation completely submerged (Source: Asrasal.2018)

\subsection{Stability Control of Structure}

Structure stability control is very important to know whether the floating foundation can float after being loaded by the upper structure of the building. In this research the 
stability control value of the structure has been determined that it is equal to 1.5. To calculate structure stability, the following equation is used:

$$
\frac{\mathrm{Fa}}{\mathrm{G}}>1.5
$$

Where:

$\mathrm{Fa} \quad$ : Floating force from the floating foundation (Newton)

G : Total weight of the floating house structure $(\mathrm{kg} / \mathrm{ton} / \mathrm{N})$

1.5 : Sefty Factor (predetermined safety number)

\section{Research method}

Before the analysis, data, which have been collected (primary and secondary data), are first processed to produce relevant information for the analysis, these data include:

1. Data of the floating house design, which function as a place to live with an area of the building $(11 \mathrm{~m} \times 9)=,99 \mathrm{~m}^{2}$ and the area of the floating foundation $(12 \mathrm{~m} \mathrm{x} 15 \mathrm{~m})=180$ $\mathrm{m}^{2}$ as shown in the following figure.

2. Technical data from the floating foundation materials In this research data analysis is needed to:

1. To calculate the structure and total weight of the floating house using SAP 2000 and Microsoft excel software.

2. To calculate the Budget Plan (RAB) of a floating house design using foundation materials made of plastic, styrofoam and bamboo drums. This calculation was conducted using Microsoft Excel software.

\section{Result and Discussion}

\subsection{Loading at the Upper Structure}

To calculate the weight of the upper structure in this research, the SAP 2000 software application was used. This application served to help calculate the amount of load in the design of the floating house, which consisted of the loads of roof, truss, column, ring beam, sloof, wall, door and window, as well as wind. While to calculate the load of fences and house floor plates, Microsoft Excel software was used. 
Table 1. The Load Calculation Result of the Floating House using SAP 2000

\begin{tabular}{|c|c|c|c|c|c|c|c|c|}
\hline \multicolumn{9}{|c|}{ TABLE: Joint Reactions } \\
\hline Joint & OutputCase & CaseType & F1 & F2 & F3 & M1 & M2 & M3 \\
\hline Text & Text & Text & Tonf & Tonf & Tonf & Tonf-m & Tonf-m & Tonf-m \\
\hline 16 & COMB1 & Combination & -0.0315 & 0.001 & 0.4644 & -0.00055 & -0.05035 & -0.00089 \\
\hline 17 & COMB1 & Combination & -0.0301 & 0.0024 & 1.0865 & -0.00372 & -0.05071 & -0.00079 \\
\hline 18 & COMB1 & Combination & -0.0144 & -0.009 & 1.1694 & 0.01441 & -0.02798 & -0.00093 \\
\hline 24 & COMB1 & Combination & -0.0171 & 0.0008257 & 0.8384 & -0.00526 & -0.03361 & -0.00283 \\
\hline 38 & COMB1 & Combination & -0.0155 & 0.0004657 & 0.7029 & 0.00003552 & -0.03602 & -0.00061 \\
\hline 39 & COMB1 & Combination & -0.0236 & 0.0035 & 1.5703 & 0.00129 & -0.04115 & -0.0009 \\
\hline 42 & COMB1 & Combination & -0.0187 & 0.0023 & 1.0126 & -0.00065 & -0.03485 & -0.00068 \\
\hline 43 & COMB1 & Combination & -0.0215 & 0.0062 & 0.695 & -0.00903 & -0.04146 & -0.00144 \\
\hline 44 & COMB1 & Combination & -0.0282 & -0.0088 & 1.5144 & 0.00011 & -0.05039 & -0.00276 \\
\hline 45 & COMB1 & Combination & -0.0139 & -0.0442 & 0.7587 & 0.0354 & -0.02794 & -0.00454 \\
\hline 46 & COMB1 & Combination & -0.0158 & 0.0037 & 0.2648 & -0.00754 & -0.02902 & -0.00301 \\
\hline 47 & COMB1 & Combination & -0.0047 & 0.0054 & 0.3534 & -0.00906 & -0.02421 & -0.00046 \\
\hline 48 & COMB1 & Combination & -0.0079 & -0.0094 & 1.1889 & 0.01177 & -0.01867 & 0.00007509 \\
\hline 49 & COMB1 & Combination & 0 & 0 & 0.005 & 0.00042 & 0 & $\underline{0}$ \\
\hline 50 & COMB1 & Combination & -0.0158 & 0.0329 & 1.3861 & -0.03596 & -0.03097 & -0.00082 \\
\hline 51 & COMB1 & Combination & -0.0257 & -0.0137 & 0.8336 & 0.01352 & -0.04467 & -0.00006671 \\
\hline 52 & COMB1 & Combination & -0.022 & 0.0002573 & 0.9981 & 0.00319 & -0.03942 & -0.00072 \\
\hline 53 & COMB1 & Combination & -0.0158 & -0.0085 & 1.4116 & 0.00517 & -0.03447 & -0.00151 \\
\hline 54 & COMB1 & Combination & -0.0369 & 0.0057 & 0.9241 & -0.00937 & -0.05496 & 0.00077 \\
\hline 56 & COMB1 & Combination & -0.0283 & -0.0016 & 0.4386 & 0.00066 & -0.04599 & -0.00087 \\
\hline 57 & COMB1 & Combination & \begin{tabular}{|l|}
-0.023 \\
\end{tabular} & -0.00061 & 0.8738 & -0.0004 & -0.04383 & -0.00096 \\
\hline 58 & COMB1 & Combination & -0.0063 & 0.0067 & 0.6247 & -0.01347 & -0.01832 & 0.00073 \\
\hline 59 & COMB1 & Combination & -0.0213 & 0.0052 & 0.3887 & -0.01133 & -0.03674 & 0.0008 \\
\hline 60 & COMB1 & Combination & -0.0171 & 0.0125 & 0.7657 & -0.01681 & -0.03289 & 0.00137 \\
\hline 61 & COMB1 & Combination & -0.0189 & 0.0068 & 0.335 & -0.0112 & -0.03195 & -0.00246 \\
\hline & & & & & & & & \\
\hline & Jun & lah Berat Tot & & & 20.6047 & Ton & & \\
\hline
\end{tabular}

From the load calculation result using software SAP 2000, it is reported that the total load of the upper structure is 20.6047 tons or $20604.7 \mathrm{~kg}$

\section{a. Load of the Upper Structure calculated using Microsoft Excel}

\section{Load on the floor plate}

Size of the floor plate $\quad: 200 \times 20 \times 0.2 \mathrm{~cm}$

Volume of the floor plate $\quad: 3.6 \mathrm{~m} 3$

Specific gravity of wood $\quad: 1.25 \mathrm{~kg} / \mathrm{cm}^{2}\left(1250 \mathrm{~kg} / \mathrm{m}^{3}\right)$

Weight of wood : Volume $\mathrm{x}$ BJ

$: 3.6 \times 1250$

: $4,500 \mathrm{~kg}$

\section{Load on the fence}

Size of wood beam

: $10 \times 10 \mathrm{~cm}$

Volume of the fence

$$
: 1.787 \mathrm{~m}^{3}
$$


Specific gravity of wood $\quad: 1.25 \mathrm{~kg} / \mathrm{cm}^{2}=1250 \mathrm{~kg} / \mathrm{m}^{3}$

Weight of wood

: Volume x BJ

: $1.787 \times 1250$

: $2,233.75 \mathrm{~kg}$

\section{b. Live load}

Occupant Load

: 6 People

Weight per person : $80 \mathrm{~kg}$ (assumption)

Total life load : $6 \times 80 \mathrm{~kg}$ : $480 \mathrm{~kg}$

The total load acting on the Upper structure is:

$=20,604.7 \mathrm{~kg}+4500 \mathrm{~kg}+2,233.75 \mathrm{~kg}+480 \mathrm{~kg}$

$=27818,45 \mathrm{~kg}$ (Downward direction)

Conversion kg - Newton

$=27,818.45 \times 10$

$=278,184.5$ Newton (Downward direction)

\subsection{Loading on the under structure}

The load on the lower structure for the floating house came from the load of the foundation framework, which was located under the sloof, composed of wooden frames, bound and integrated with the structure of the floating house.

\section{a. Framework Load of the foundation}

\section{Vertical Wood Beam Load}

Size

: $8 \times 12 \mathrm{~cm}$

Volume

: $3,456 \mathrm{~m} 3$

Specific gravity of wood

$: 1.25 \mathrm{~kg} / \mathrm{cm}^{2}\left(1250 \mathrm{~kg} / \mathrm{m}^{3}\right)$

Weight of wood

: Volume x BJ

: 3,456 x 1250

: 4,320 kg

\section{Horizontal wood beam load}

Size

$: 8 \times 12 \mathrm{~cm}$

Volume

: $3,456 \mathrm{~m}^{3}$

Specific gravity of wood

$$
: 1.25 \mathrm{~kg} / \mathrm{cm}^{2}\left(1250 \mathrm{~kg} / \mathrm{m}^{3}\right)
$$


Weight of wood

: Volume x BJ

: $3,456 \times 1250=4,320 \mathrm{~kg}$

The total load acting on the lower structure: the total load of foundation framework

$=4,320 \mathrm{~kg}+4,320 \mathrm{~kg}=8,640 \mathrm{~kg}$ (Downward direction)

Conversion $\mathrm{kg}-$ Newton

$=8,640 \times 10=86,400$ Newton (Downward direction)

\subsection{Total weiht of structure $(G)$}

Based on the results in the load calculation of the upper and lower structures for the floating house design, the total weight of the house is:

Total structure weight due to working load:

Total Load of the upper structure + Total Load of the lower structure

$=27818,45+8640 \mathrm{~kg}$

$=36458,45 \mathrm{~kg}$ (downward)

Conversion of $\mathrm{Kg}$ to Newton

$=36458,45 \mathrm{~kg} \times 10$ (downward)

$=364.585,5$ Newton (downward)

\subsection{Floating Force Analysis (Fa)}

Floating force analysis $(\mathrm{Fa})$ refers to the analysis of the magnitude of the floating force in a floating foundation material, which will be compared to the downward force due to the weight of the floating structure. A floating foundation is considered strong or stable when the upward force $(\mathrm{Fa})$ is more than the total weight of the structure $(\mathrm{G})$. In this research, the comparison value between the magnitude of the floating force and the weight of the house structure is 1.5. The followings are a comparison of the force among the three materials (plastic, Styrofoam and bamboo drum).

\subsection{The analysis of floating foundation made of plastic drum}

Based on the calculation results in the analysis, it is revealed that the magnitude of the floating force $(\mathrm{Fa})$ is 549814 Newton (upward), using 232 plastic drum as the foundation materials. Therefore, the foundation system was made in one layer with the arrangement as shown in Figure 2. below. 


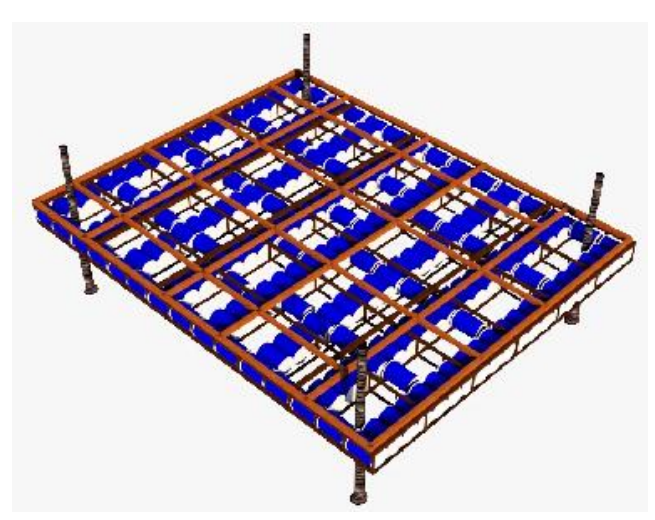

Figure 2. Placement detail of plastic drum as the floating foundation material (as many as 232 pieces)

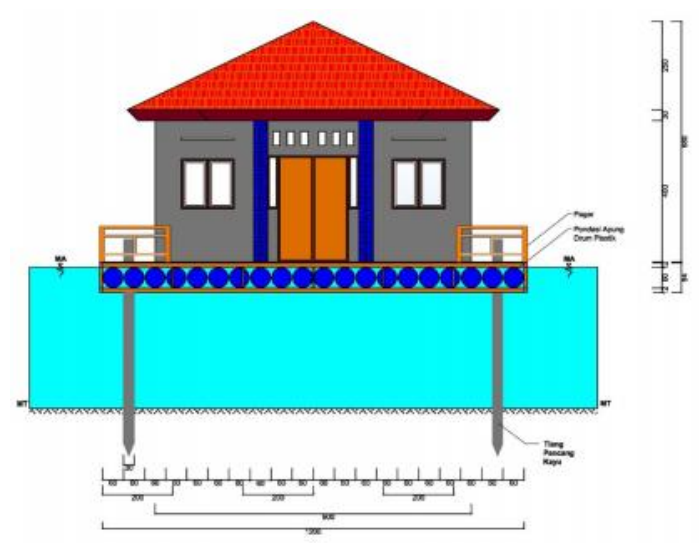

Figure 3. Front view of the floating house with the plastic drum as the foundation material

The calculation analysis of the Styrofoam as the floating foundation material. Based on the calculation results above, the floating force (Fa) is 552.720 Newton (upward), using 56 pieces of Styrofoam as the foundation material. Therefore, the foundation system is made in one layer with the arrangement as shown in Figure 4 below.

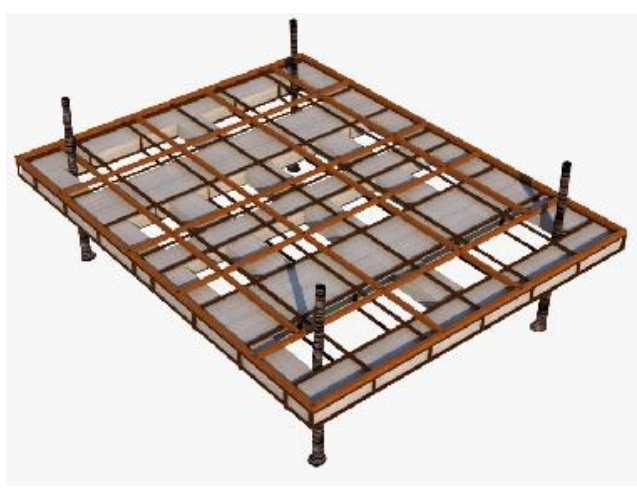

Figure 4. Placement detail of Styrofoam asthe floating foundation material (as many as 56 sheets)

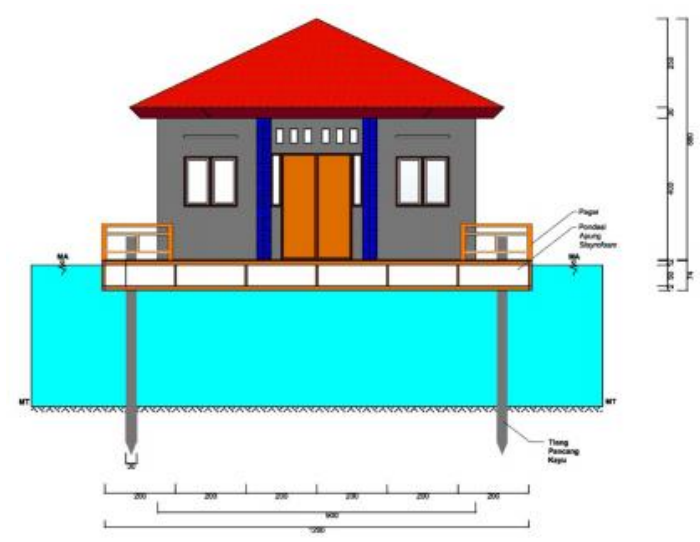

Figure 5. The front view of the floating house with Styrofoam as the foundation material

\subsection{The calculation analysis of bamboo as the floating foundation material}

Based on the result in the analytical calculation above, it can be inferred that the floating force (Fa) magnitude is 540.833 Newton (Upward), using 3,900 sticks of bamboo as the foundation material. This bamboo had the length of 5 meter and the diameter of $0.1 \mathrm{~m}$. 
Therefore, the foundation system was made by tying the bamboo on the beam of $6 \mathrm{~cm} \times 12$ $\mathrm{cm}$, with the length of 5 meter, with the width of 1 meter, and with the thickness of 1.5 meter, filled up with 150 sticks for one bunch of bamboo. There are as many as 26 bunch of bamboo and all were installed one layer with the arrangement as shown in figure 6 below.

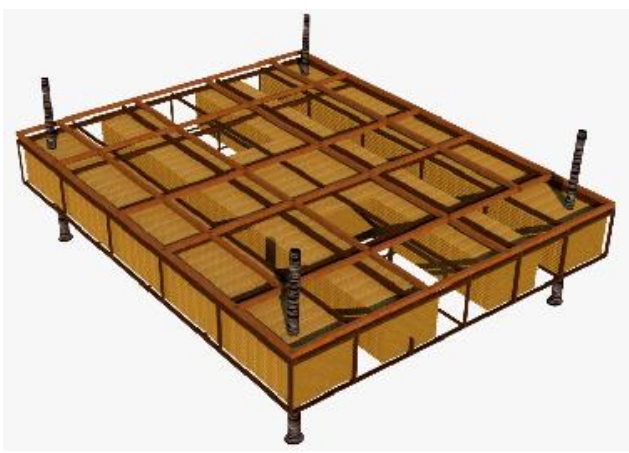

Figure 6. Placement detail of bamboo as the floating foundation material (as many as 3900 sticks)

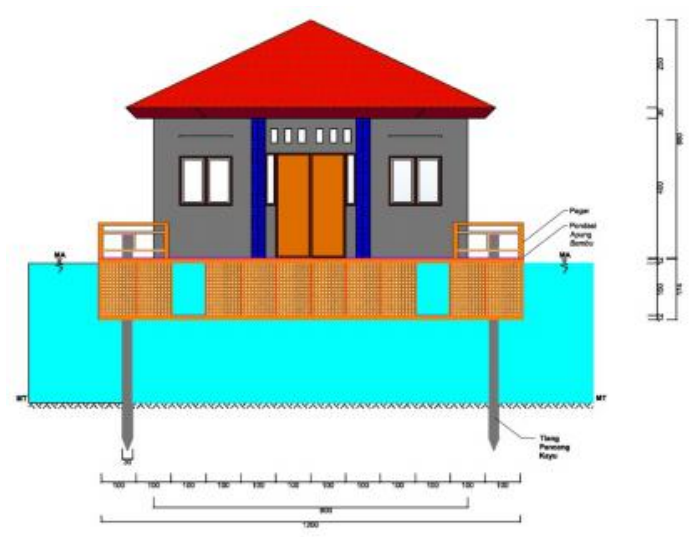

Figure 7. The front view of the floating house with bamboo foundation

\subsection{Comparison Summary of the Three Material Foundations}

This recapitulation aims to find out in detail the results in this research pertaining to the use of the three types of foundation materials, and to find out the comparison, starting from the floating force $(\mathrm{Fa})$, the amount of foundation material, the stability control of the structure and the total amount of the Budget Plan. For more information, details can be seen in the following table:

Table 2. The recapitulation result in the three material comparison

\begin{tabular}{c|l|c|c|c|l}
\hline No. & $\begin{array}{c}\text { Floating } \\
\text { Foundation } \\
\text { Materials }\end{array}$ & Floating force (Fa) & $\begin{array}{c}\text { The amount } \\
\text { of materials }\end{array}$ & $\begin{array}{c}\text { Stability } \\
\text { control }\end{array}$ & Value of budgeting plan \\
\hline 1 & Plastic drum & 549,814 Newton & 232 Pieces & 1.5 & IDR. 358,270,000.00 \\
\hline 2 & Styrofoam & 552,720 Newton & 56 Sheets & 1.5 & IDR.360,140,000.00 \\
\hline 3 & Bamboo & 540,883 Newton & 3900 Sticks & 1.5 & IDR. 369,066,000.00 \\
\hline
\end{tabular}

\section{Conclusion}

Based on the analysis result in the discussion of the previous chapters, it can be concluded as follows:

1. From the analysis result in the discussion, it is revealed that the total weight of the floating house structure $(\mathrm{G})$ is $36,585.5$ Newton (downward), the safety number allowed 
in the research is 1.5 , so the floating force magnitude $(\mathrm{Fa})$ is obtained among the three foundation materials:
a. Plastic drum as the foundation material
: 549.814 Newton ( Upward )
b. Styrofoam as the foundation material
: 552,720 Newton ( Upward )
c. Bamboo as the foundation material
: 540.883 Newton ( Upward )

2. From the analysis result, it can be reported that the amount of foundation materials of each type of the floating foundation is as follow:
a. Plastic drum as the foundation material : 232 pieces
b. Styrofoam as the foundation material : :56 slices
c. Bamboo as the foundation material : 3900 pieces

3. From the result in the calculation analysis of the budget plan, it is revealed that the total expenses from each foundation are as follow:

a. The budget plan value of plastic drum as the foundation material Rp. 358,270,000.00

b. The budget plan value of styrofoam as the foundation material Rp. 360,140,000.00

c. The budget plan value of bamboo as the foundation material Rp. 369,066,000.00

From the results of the above analysis, it can be concluded that design of the floating house using plastic drum as the floating foundation material is cheaper or economical compared to the floating foundation made of either Styrofoam or bamboo.

\section{REFERENCES}

Aswat Asrasal ,2018, Analisis Kestabilan Planform Rumah Apung Dengan Menggunakan Bahan yang Adaptif, Universitas Islam Sultan Agung Semarang.

Andika dan Eko, 2015." Analisis Kekuatan Baja Canai Dingin (Cold Formed Steel) Sebagai Alternatif Untuk Elemen Struktur Balok Rumah Sederhana Yang Merespon Gempa". Sekolah Tinggi Tekologi Garut. "Jurnal Kalibrasi”. Volume 13, No 1, November 2015.

Ardi dan Beni, 2014." Pasar Terapung Di Banjarmasin Kalimantan Selatan". Universitas Kristen Petra. Jurnal e Dimensi Arsitektur Volume 2, No 1, Juli 2014.

B-Panel." Pondasi Rumah Apung Menggunakan Bahan Styrofoam". Diperoleh 24 Februari 2019 dari http://www.b-panel.com/b-panel-questions-answers)

Dimas Hastama Nugraha, Primanda Kiky Widyaputra, 2016. "Kesiapan Masyarakat Tambaklorok dalam Menerima Menerima Rencana Revitalisasi Kawasan Menggunakan 
Teknologi Apung". Balai Litbang Penerapan Teknologi Permukiman, Institut

Teknologi Yogyakarta ,2016

Dido Cahya Mahardika, Triwilaswandio WP., 2017. "Analisis Teknis dan Ekonomis Pengembangan Industri Rumah Apung Sebagai Pendukung Wisata Bahari Indonesia", Departemen Teknik Perkapalan, Fakultas Teknologi Kelautan, Institut Teknologi Sepuluh Nopember (ITS), Jurnal Teknik ITS Vol. 6, No.2, 2017

M.Awaludin Hamdy, Arman Setiawan 2017. "Model Pengembangan Struktur dan Bahan

Pada Elemen Tiang / Kaki ( Super Structur) Pada Permukiman Rumah Tradisional Bugis Makasar di Kawasan Pesisir Kota Makasar". Fakultas Teknik Universitas Bosowa, Sinaltsub -I, 4 Desember 2017

Naidah Naing, Haryanto Halim, 2013."Sistem Struktur Rumah Mengapung di Danau Tempe Sulawesi Selatan”.Universitas Muslim Indonesia. "Jurnal Permukiman Vol. 8 No. 3 November Tahun 2013

PKKI NI -5, 2013.." Tata Cara Perencanaan Konstruksi Kayu Indonesia" . Standar Nasional Indonesia. Revisi ke 5.

S. Imam Wahyudi, 2016. "Perencanaan Floating Podium di Polder Stasinu Tawang". Proposed Floating House. Semarang 2016.

Sudarman, 2015." Bamboo as a material structure of floating house construction at lake tempe kabupaten Wajo Sulawesi Selatan"Institute Technologhy Bandung, Seminar Nasional \#6 : 2015, “Finding The Fifth Element after water eart, wind, and fire" Lokal wisdom an cultural sustainability, 2015

Sugiri, 2016." Analisa Gaya Apung (Buoyancy) Pada Sistem Perpipaan Gas di Area Flowline dan Trunkline". Universitas Muslim Indonesia dan Universitas Hasanudin. "Jurnal Geomine" Volume, 4 No.3, Desember 2016.

"Sepuluh Konsep Rumah Terapung Paling Keren U nuk dan Gila di Dunia". Diperoleh tanggal 28 februari 2018 dari http://www.tentik.com/alamak-inilah-10-konsep-rumah-terapungpaling-keren-unik-dan-gila-di-dunia/

Wijaya, 2014." Perancangan Perangkat Lunak Perancangan Sambungan Kayu Berdasarkan SIN 7973-2103 Dengan Alat Sambungan Baut ". Universitas Kristen Maranatha. "Jurnal Teknik Sipil” Volume 10, No 2, Oktober 2014. 
Zakki, 2014." Perencanaan Bangunan Apung Dan Keramba Dengan Sitem Modular Ponton Berbahan Ferosemen".Universitas Diponegoro. "Jurnal Teknik Perkapalan" Volume.4, No.3 Tahun 2014. 